Full-text Available Online at www.ajol.info and www.bioline.org.br/ja

\title{
Effect of Consuming Rooftop Harvested Rainwater from Esan Communities in Edo State Nigeria on Some Biochemical, Haematological Parameters and Electrolytes of Wistar Albino Rats
}

\author{
*11BELONWU, DC; OTEDO, JO; WEGWU, MO \\ Department of Biochemistry, University of Port Harcourt Port Harcourt Nigeria \\ * Author for correspondence. Email:chukkabell2000@ gmail.com
}

\begin{abstract}
This study assessed the effects of some local sources of drinking water in Okiagbem, Uromi and Ubiaja communities of Esan Edo State Nigeria on the biochemical, haematological parameters and electrolytes of Wistar albino rats. The Urea values of all the test groups $(4.90 \pm 0.59,5.95 \pm 0.74$ and $5.70 \pm 0.71)$ were slightly higher than that of the control $(3.87 \pm 0.39$ and there was a significant $(\mathrm{p} \geq 0.05)$ increase in blood Creatinine levels of all the test groups $(79.83 \pm 10.39,101.67 \pm 13.54$ and 97.67 \pm 8.76$)$ compared with the control $(67.33 \pm 7.81)$, indicating renal damage. There was an increase in Total and Conjugated Bilirubin of the test groups compared with the control. There was no significant $(\mathrm{p} \geq 0.05)$ increase in Electrolytes' concentrations between the test groups and control. .The PCV values range of $35.17 \pm 1.45 \%$ to $38.00 \pm 2.67 \%$ for all samples were not significantly $(\mathrm{p} \geq 0.05)$ different from the Control values $(36.00 \pm 1.93 \%)$. There were significant $(\mathrm{p} \geq 0.05)$ increases in the TWBC counts of Uromi and Ubiaja test groups. The liver function test conducted showed a significant $(\mathrm{p} \geq 0.05)$ increase in ALT, AST and ALP with the variations indicating liver damage.(C JASEM
\end{abstract}

\section{http://dx.doi.org/10.4314/jasem.v18i1.15}

Introduction: Rainwater harvesting from household rooftops and storage in underground cement tanks have been widely used as an alternative source of water for domestic use in developing countries. It is especially essential in Africa in general and Nigeria in particular, owing to its cost effectiveness and ease of maintenance for effective long-term system operation.

Despite the prevalent use of this method in developing countries for mitigating the growing urban water crisis and as a supplementary source of water supply to already existing public water supply scheme, particularly in areas with dispersed population (Eruola et al. 2010), there are concerns that rooftop harvested rainwater stored in underground concrete tanks does not often meet the bacteriological quality standards prescribed for drinking water. International reviews have shown that the quality of harvested water from rooftop catchments often does not meet the drinking-water guideline values. Most of the studies from different parts of the world reveal that harvested water is heavily contaminated microbiologically by a variety of indicator and pathogenic organisms unless special care is taken during collection and storage of rainwater (Meera and Ahammed 2006).
The aim of this paper is to report on some biochemical, haematological and electrolytes of Wistar Albino Rats that consumed rooftop harvested rainwater obtained from some Esan Communities in Edo State Nigeria.

\section{MATERIALS AND METHODS}

Test Materials: Rooftop harvested rainwater stored in underground concrete tanks were collected from individual household tanks from three different Esan Communities of Edo State: Uromi, Ubiaja and Okiagbem Communities. The water samples were collected with 2 litre plastic hydro-bios water samplers and transferred to clean $250 \mathrm{ml}$ capacity borosilicate glass bottles. Samples were stored at $40^{\circ} \mathrm{C}$ and immediately taken to the laboratory for analysis.

Experimental Animals: Male wistar albino rats weighing between 100-150g were chosen for the study. The rats were obtained from the animal house, University of Port Harcourt, Nigeria. The animals were allowed to acclimatize for two weeks prior to the study. They were housed in clean cages and maintained under standard laboratory condition of 12 $\mathrm{h}$ natural light and $12 \mathrm{~h}$ darkness at ambient room temperature. The rats were fed with screened

*Corresponding author. Email:: chuka.belonwu@uniport.edu.ng 
standard pellets and the appropriate rainwater sample previously analysed for physicochemical parameters was made available to each group of rats ad libitum and were also given the water orally every 12 hours.

Study Design: Healthy adult male rats were used in this experiment. Animals were randomly assigned to the cages and each animal was marked for identification. The rats were divided into four groups of 8 animals in each group. The rats in group 1 (control group) received $1 \mathrm{~mL}$ of distilled water orally. The rats in group 2, 3 and 4 were given $1 \mathrm{~mL}$ of rainwater from Okiagbem, Uromi and Ubiaja by oral route, respectively. The treatment took place for four weeks after which the animals were sacrificed.

Statistical Analysis: The experimental results were expressed as the Mean \pm SEM of three determinations. The ANOVA test was used to assess for any statistically significant differences between the treatment and control groups at $\mathrm{P}<0.05$. The treatment means were separated using Duncan's Multiple Range Test (DMRT).

\section{RESULTS AND DISCUSSION}

Effect of treatment on some Haematological Parameters of Albino Wistar Rats: The results of the effect of the rainwater on some haematological parameters of albino wistar rats are shown below in Table 1. The parameters analysed were Packed Cell Volume (PCV), Total White Blood Cell (TWBC), neutrophils, lymphocytes, eosinophils and monocytes. The result showed that the PCV value for rats fed with water from Okiagbem $(38.00 \pm 2.67 \%)$ was slightly higher than those fed with water from Uromi $(35.17 \pm 1.45 \%)$ and Ubiaja $(36.6 \pm 0.997 \%)$ and even the control $(36.00 \pm 1.93 \%)$. Rats fed with water samples from Uromi and Ubiaja recorded higher TWBC values of $10.18 \pm 1.81 \mathrm{~g} / 1$ and $10.00 \pm 1.49 \mathrm{~g} / \mathrm{l}$ respectively while rats fed with water from Okiagbem had TWBC values of $7.28 \pm 0.96 \mathrm{~g} / \mathrm{l}$. There was increase in the serum level of lymphocytes

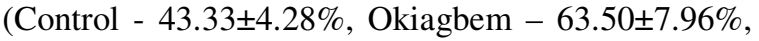
Uromi $-60.33 \pm 9.07 \%$ and Ubiaja - 60.67 $\pm 8.84 \%$ respectively).

TABLE 1: Effect of Rainwater Samples on some Haematological Parameters of Albino Wistar Rats

\begin{tabular}{|c|c|c|c|c|}
\hline Parameter(s) & Control & Okiagbem & Uromi & Ubiaja \\
\hline PCV (\%) & $36.00 \pm 1.93^{(a)}$ & $38.00 \pm 2.67^{(\mathrm{a})}$ & $35.17 \pm 1.45^{(\mathrm{a})}$ & $36.67 \pm 0.99^{(a)}$ \\
\hline TWBC $(\mathrm{g} / \mathrm{l})$ & $7.83 \pm 0.57^{(\mathrm{a})}$ & $7.28 \pm 0.96^{(\mathrm{a})}$ & $10.18 \pm 1.81^{(\mathrm{a})}$ & $10.00 \pm 1.49^{(\mathrm{a})}$ \\
\hline Neutrophil (\%) & $56.33 \pm 4.36^{(\mathrm{a})}$ & $37.00 \pm 8.31^{(\mathrm{a})}$ & $39.33 \pm 9.23^{(\mathrm{a})}$ & $38.17 \pm 7.75^{(a)}$ \\
\hline Lymphocytes (\%) & $43.33 \pm 4.28^{(\mathrm{a})}$ & $63.50 \pm 7.96^{(\mathrm{a})}$ & $60.33 \pm 9.07^{(\mathrm{a})}$ & $60.67 \pm 8.84^{(\mathrm{a})}$ \\
\hline Eosinophils (\%) & $0.33 \pm 0.21^{\text {(a) }}$ & $0.50 \pm 0.34^{(\mathrm{a})}$ & $0.33 \pm 0.33^{(\mathrm{a})}$ & $0.33 \pm 0.21^{(\mathrm{a})}$ \\
\hline Monocytes (\%) & $0.00 \pm 0.00^{(\mathrm{a})}$ & $0.00+0.00^{(\mathrm{a})}$ & $0.00+0.00^{(\mathrm{a})}$ & $0.00 \pm 0.00^{(\mathrm{a})}$ \\
\hline
\end{tabular}

The data are presented as MEAN \pm SEM, $n=3$.

Means with the same alphabet are not statistically significant at $(\mathrm{P} \leq 0.05)$.

Packed cell volume (PCV) also known as erythrocyte volume fraction $(\mathrm{EVF})$ or haematocrit is considered an integral part of a person's complete blood count result, alongside with haemoglobin concentration, white blood cell count and platelet count (Purves et $a l, 2004)$. It is a measure of the percentage of red blood cells to the total blood volume. A low PCV may indicate anaemia, blood loss, bone marrow failure multiple myeloma, nutritional deficiencies etc. A high PCV may indicate dehydration (for example, due to burns or diarrhoea), eclampsia (a serious condition that can occur during pregnancy) or polycythaemia vera. The results of this experiment showed the PCV values to be within the range of $35.17 \pm 1.45 \%$ to $38.00 \pm 2.67 \%$. There was no significant $(\mathrm{P} \leq 0.05)$ difference between the test and the control values.

White blood cells are cells of the immune system involved in defending the body against both infectious diseases and foreign materials (LafleurEffect of Treatment on Enzyme Parameters
Brooks, 2008). The number of leucocytes in the blood is often an indicator of disease. With the exception of Okiagbem which recorded $7.28 \pm 0.96 \mathrm{~g} / \mathrm{l}$, there were increases in the TWBC concentration of the rooftop water from Uromi $(10.18 \pm 1.81 \mathrm{~g} / \mathrm{l})$ and Ubiaja $(10.00 \pm 1.49 \mathrm{~g} / \mathrm{l})$. The increase in white blood cells could be due to the presence of foreign materials or infectious disease caused by the administration of the rooftop water.

Lymphocytes are the main effector cells of the immune system. They determine the specificity of the immune response to infectious micro-organisms and other foreign substances (Mitchell et al, 2001). Lymphocytes were found to be highest in Okiagbem with a value of $63.50 \pm 7.96 \%$; with $60.67 \pm 8.84 \%$, $60.33 \pm 9.07 \%$, and $43.33 \pm 4.28 \%$ for Ubiaja, Uromi and Control respectively. Eosinophil had a value of $0.50 \pm 0.34 \mathrm{mg} / \mathrm{l}$ for Okiagbem and $0.33 \pm 0.21 \mathrm{mg} / \mathrm{l}$ for all the other samples. 


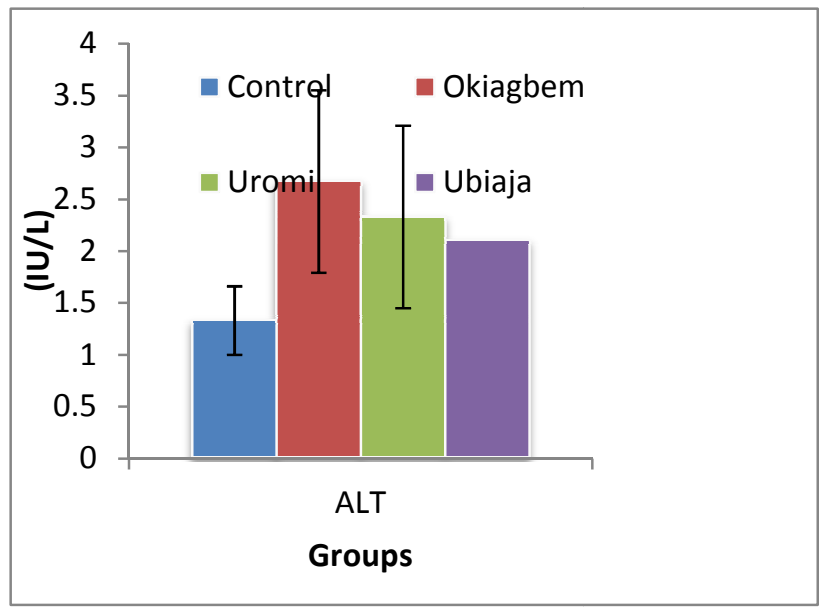

Fig 1. Effect of treatment on Alanine transaminase levels in wistar Albino rats

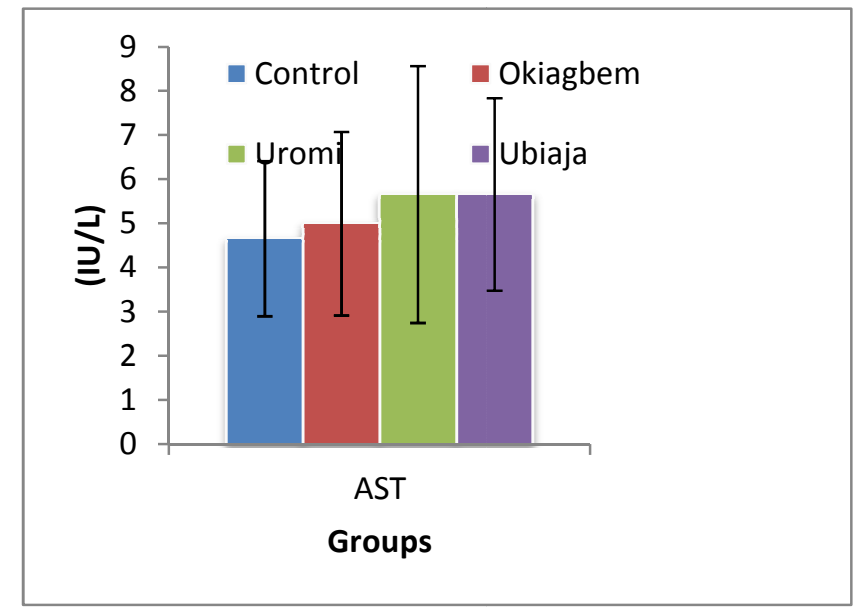

Fig 2 Effect of treatment on Aspartate transaminase levels in wistar Albino rats

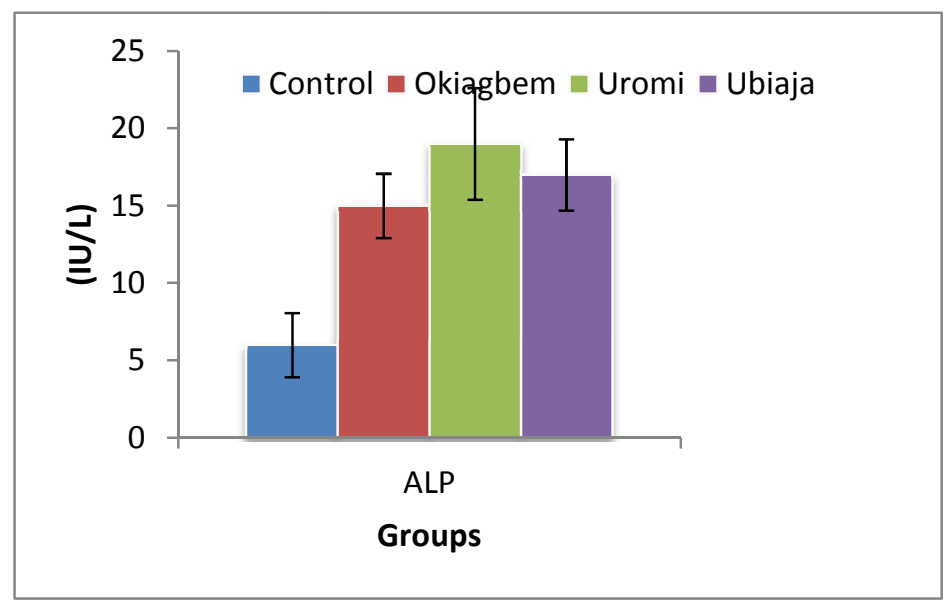

Fig 3. Effect of treatment on Alkaline Phosphatase levels in wistar Albino rats

Generally, analyses of the activities of some basic liver function enzymes in the plasma or serum can be used to indirectly access the integrity of tissues after being exposed to certain pharmacological agent(s). These enzymes are usually liver markers whose plasma concentrations above the homeostatic limits could be associated with various forms of disorders which affect the functional integrity of the liver tissues. Alkaline phosphatase and alanine transaminase are marker enzymes of damage for the plasma membrane and endoplasmic reticulum (Shahjahan $e$ tal, 2004). They are frequently used to assess the integrity of the plasma membrane and tissues after being exposed to certain pharmacological agents (Akanji e tal, 1993).
The results of this study showed that the level of ALP was significantly $(\mathrm{P} \leq 0.05)$ higher in rats administered water from Okiagbem $(15.0 \pm 2.08 \mathrm{IU} / \mathrm{L})$, Uromi $(19.0 \pm 3.61 \mathrm{IU} / \mathrm{L})$ and Ubiaja $(17.0 \pm 2.31 \mathrm{IU} / \mathrm{L})$ than the control $(6.00 \pm 2.08 \mathrm{IU} / \mathrm{L})$.

AST had a similar trend: Control $(4.66 \pm 1.76 \mathrm{IU} / \mathrm{L})$, Okiagbem (5.00 $\pm 2.08 \mathrm{IU} / \mathrm{L})$, Uromi $(5.66 \pm 2.91 \mathrm{IU} / \mathrm{L})$ and Ubiaja $(5.66 \pm 2.18 \mathrm{IU} / \mathrm{L})$. ALT was highest in rats fed water from Okiagbem $(2.67 \pm 0.88 \mathrm{IU} / \mathrm{L})$ and Uromi $(2.33 \pm 0.88 \mathrm{IU} / \mathrm{L})$ than Ubiaja $(2.10 \pm 0.00$ $\mathrm{IU} / \mathrm{L}$ ), while Control was $1.33 \pm 0.33 \mathrm{IU} / \mathrm{L}$.

These variations in enzyme levels between the Control and Test groups indicate that accumulation of the rainwater resulted in liver damage of the albino wistar rats. 
Effect of Treatment on Biochemical Parameters in Albino Wistar Rats: The results of the effect of the rainwater on some biochemical parameters in albino wistar rats are shown in Table 2. The parameters analysed were urea, creatinine, total and conjugated bilirubin, total protein, and albumin. From the result, it was observed that the urea value for rats fed with water from Uromi $(5.95 \pm 0.74)$ was slightly higher than those fed with water from Ubiaja $(5.7 \pm 0.71)$ and Okiagbem (4.90 \pm 0.59$)$. Rats fed with water samples from Uromi and Ubiaja recorded higher creatinine levels of $101.67 \pm 13.54 \mathrm{~g} / \mathrm{l}$ and $97.67 \pm 8.76 \mathrm{~g} / \mathrm{l}$ respectively as against $67.33 \pm 7.81 \mathrm{~g} / \mathrm{l}$ of the control. Rats fed with water from Okiagbem, Uromi, Ubiaja and Control had total bilirubin levels of $6.37 \pm 1.35 \mu \mathrm{mol} / 1,6.87 \pm 1.28 \mu \mathrm{mol} / 1,6.30 \pm 0.64 \mu \mathrm{mol} / 1$ and $4.00 \pm 0.67 \mu \mathrm{mol} / 1$ respectively. There was increase in the serum level of total protein (Control $56.67 \pm 5.28 \mathrm{~g} / \mathrm{dl}$, Okiagbem $59.00 \pm 9.28 \mathrm{~g} / \mathrm{dl}$, Uromi $68.83 \pm 5.54 \mathrm{~g} / \mathrm{dl}$ and Ubiaja $57.83 \pm 4.08 \mathrm{~g} / \mathrm{dl}$ respectively).

TABLE 2. Effect of Rainwater on some Biochemical Parameters of Albino Wistar Rats

\begin{tabular}{llllll}
\hline S/N & Parameters & Control & Okiagbem & Uromi & Ubiaja \\
\hline 1. & Urea & $3.87 \pm 0.39^{(\mathrm{a})}$ & $4.90 \pm 0.59^{(\mathrm{a})}$ & $5.95 \pm 0.74^{(\mathrm{ab})}$ & $5.70 \pm 0.71^{(\mathrm{b})}$ \\
$\mathbf{2 .}$ & $\begin{array}{l}\text { Creatinine } \\
(\mu \mathrm{mol} / \mathrm{l})\end{array}$ & $67.33 \pm 7.81^{(\mathrm{a})}$ & $79.83 \pm 10.39^{(\mathrm{c})}$ & $101.67 \pm 13.54^{(\mathrm{b})}$ & $97.67 \pm 8.76^{(\mathrm{b})}$ \\
$\mathbf{3 .}$ & $\begin{array}{l}\text { Total Bilirubin } \\
(\mu \mathrm{mol} / \mathrm{l})\end{array}$ & $4.00 \pm 0.67^{(\mathrm{a})}$ & $6.37 \pm 1.35^{(\mathrm{b})}$ & $6.87 \pm 1.28^{(\mathrm{b})}$ & $6.30 \pm 0.64^{(\mathrm{b})}$ \\
$\mathbf{4 .}$ & $\begin{array}{l}\text { Conj. Bilirubin } \\
(\mu \mathrm{mol} / \mathrm{l})\end{array}$ & $2.53 \pm 0.72^{(\mathrm{a})}$ & $2.17 \pm 0.67^{(\mathrm{a})}$ & $4.05 \pm 0.53^{(\mathrm{a})}$ & $2.80 \pm 0.47^{(\mathrm{a})}$ \\
$\mathbf{5 .}$ & $\begin{array}{l}\text { Total Protein } \\
(\mathrm{g} / \mathrm{dl})\end{array}$ & $56.67 \pm 5.28^{(\mathrm{a})}$ & $59.00 \pm 9.28^{(\mathrm{a})}$ & $68.83 \pm 5.54^{(\mathrm{b})}$ & $57.83 \pm 4.08^{(\mathrm{a})}$ \\
$\mathbf{6 .}$ & $\begin{array}{l}\text { Albumin } \\
(\mathrm{g} / \mathrm{dl})\end{array}$ & $32.00 \pm 2.19^{(\mathrm{a})}$ & $31.33 \pm 3.41^{(\mathrm{a})}$ & $42.17 \pm 5.59^{(\mathrm{a})}$ & $37.67 \pm 3.20^{(\mathrm{a})}$ \\
\hline
\end{tabular}

The data are presented as MEAN \pm SEM, $n=3$.

Means with the same alphabet are not statistically significant at $(\mathrm{P} \leq 0.05)$.

The biochemical indices monitored in the serum can be used as "markers" for assessing the functional capacity of the liver, kidneys etc. (Yakubu $e$ tal, 2003). These parameters of organ functions if altered will impair the normal functioning of the organs.

The liver produces urea in the urea cycle as a waste product of protein metabolism. An elevated level of urea nitrogen in the bloodstream may be an indication of renal failure or dehydration. The urea values from rats of the test groups were higher than the control, with Okiagbem, Uromi and Ubiaja recording $4.90 \pm 0.59, \quad 5.95 \pm 0.74$ and $5.70 \pm 0.71$ respectively as against $3.87 \pm 0.39$ of the Control. The increase in urea concentration may be due to presence of contaminants present in the rainwater.

Creatinine is a metabolic by-product of muscle metabolism. It passes into the bloodstream and is usually passed out in the urine. Creatinine is used as a marker for renal function. An elevated blood level of creatinine is an indication that the kidney may not be functioning properly. The values measured for creatinine in this study reflect a significant increase in blood creatinine in all samples when compared with the control $(67.33 \pm 7.81 \mu \mathrm{mol} / \mathrm{l})$. The highest value was recorded for rats fed with water from Uromi $(101.67 \pm 13.54 \mu \mathrm{mol} / \mathrm{l})$ while those fed water from Okiagbem recorded the lowest concentration of blood creatinine $(79.83 \pm 10.39 \mu \mathrm{mol} / \mathrm{l})$. Ubiaja had a concentration of $97.67 \pm 8.76 \mu \mathrm{mol} / 1$.

Bilirubin, a metabolic breakdown product that result from the breakdown of haemoglobin molecules from worn out red blood cells, is also one of the most commonly used liver function tests (Shahjahan $e \mathrm{tal}$, 2004). Increase in the total and conjugated bilirubin could be as a result of the breakdown of heme caused by the intake of rainwater which may contain contaminants that could affect normal organ function.

Electrical impulses are needed by the body to make muscle cells contract. The generation of electrical impulses by a cell requires an electrical voltage to be maintained across the membrane of that cell. The difference in electrolyte levels creates and maintains these electrical voltages (Cosol e tal, 2008). The level of electrolyte in the body fluid compartments are controlled by the movement of electrolytes in or out of those compartments. 
Effect of Treatment on Electrolyte Levels

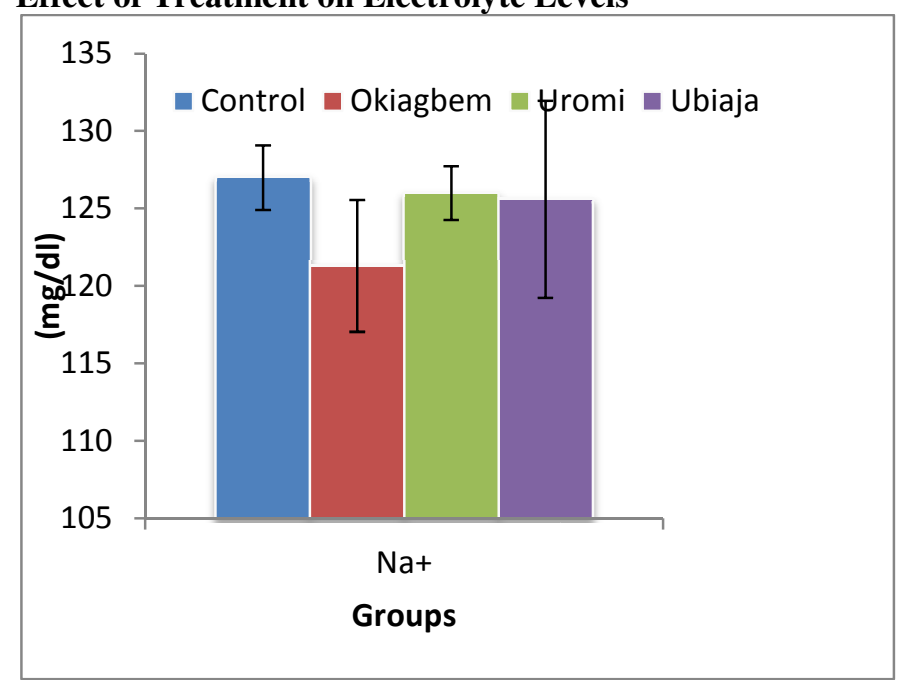

Fig 4. Effect of treatment on Sodium levels in Wistar Albino rats

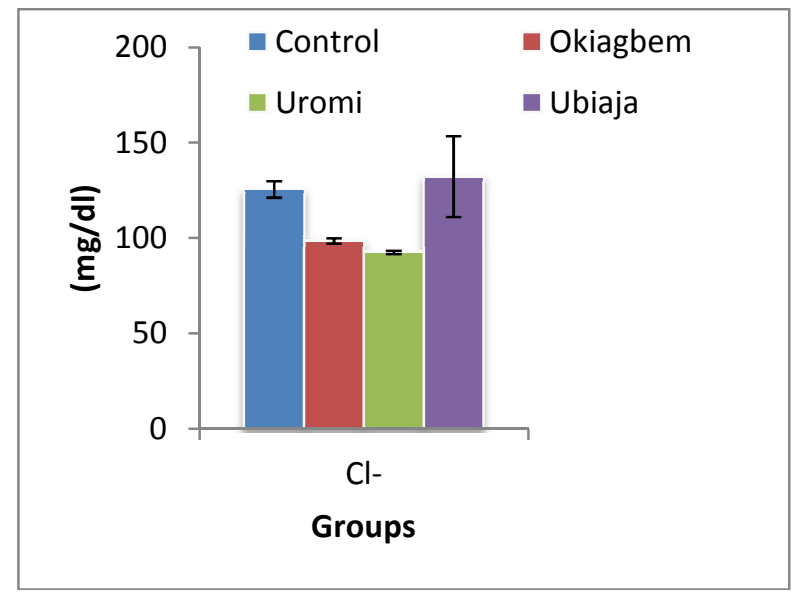

Fig 6. Effect of treatment on Chloride levels in Wistar Albino rats

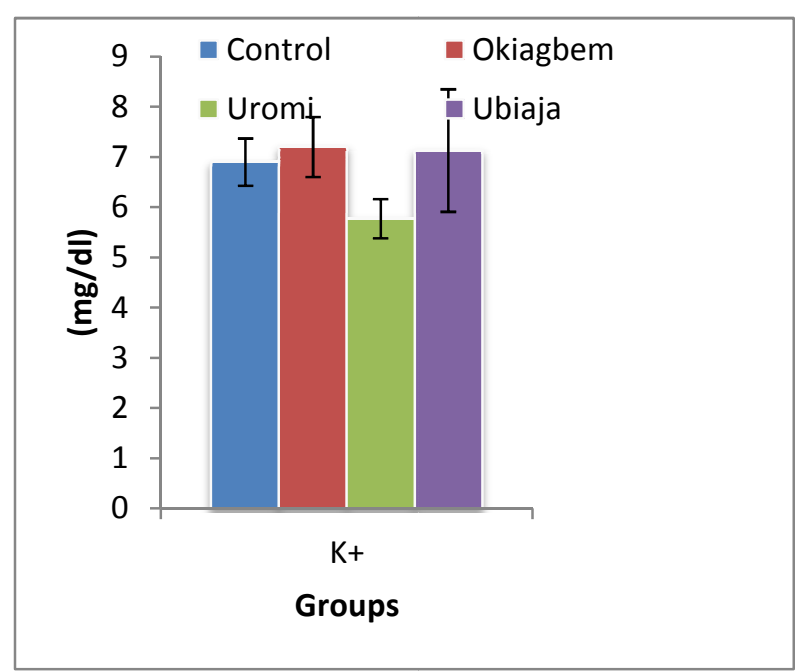

Fig 5. Effect of treatment on Potassium levels in Wistar Albino rats

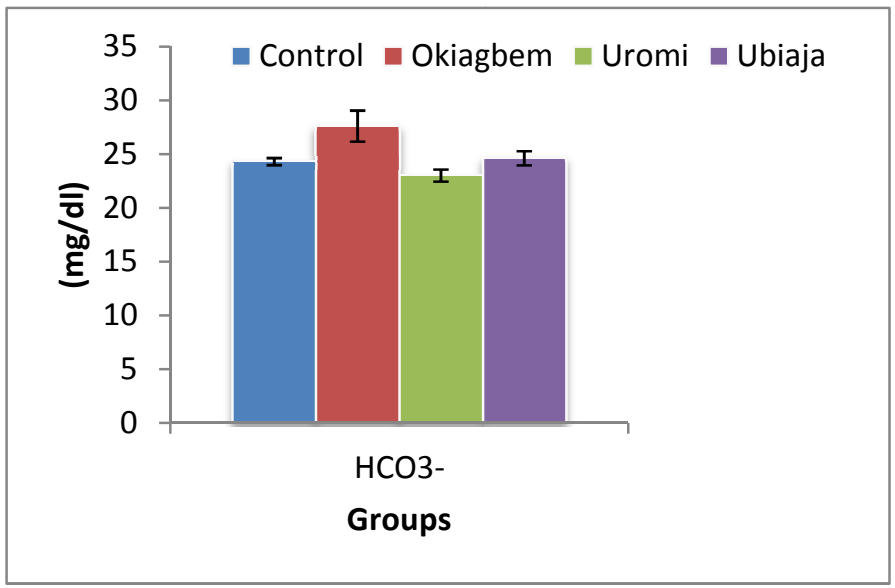

Fig 7. Effect of treatment on Bicarbonate levels in Wistar Albino rats
Sodium plays a major role in regulating the amount of water in the body. Also, the passage of sodium in and out of the cells is necessary for many body functions such as transmitting electrical signals in the brain and muscles. The level of sodium is measured to detect whether there is the right balance of sodium and liquid in the blood. The result of this experiment showed no significant $(\mathrm{p} \leq 0.05)$ difference between the sodium ion concentration of the control and that of the Uromi group, but there was significant $(\mathrm{p} \leq 0.05)$ difference between the control values and that of the Okiagbem and Ubiaja groups. The level of $\mathrm{Na}^{+}$in the control was slightly higher than those of the test samples.

Also, no significant $(\mathrm{p} \leq 0.05)$ difference was observed between the levels of potassium $\left(\mathrm{K}^{+}\right)$ions in the
Control group and those of the Okiagbem and Uromi groups, but there was significant $(\mathrm{p} \leq 0.05)$ difference between the potassium ion levels of the Control and that of the Ubiaja group.

There was significant $(\mathrm{p} \leq 0.05)$ difference between the chloride $\left(\mathrm{Cl}^{-}\right)$ion concentrations of the control group and those of the test groups. There was significant $(\mathrm{p} \leq 0.05)$ difference between the bicarbonate $\left(\mathrm{HCO}_{3}{ }^{-}\right)$ion concentrations of the Control group and test groups.

Conclusion and Recommendation: The results of this study showed that the sources of drinking waters in the study areas had some harmful effects on the test animals; therefore, residents of these Communities 
should ensure that rooftop rainwater collected in the water reserviours to adequate treatment before drinking.

\section{REFERENCES}

Aimienwalan, A.(1990). Customs and Tradition of Esan People, Esan Vision magazine, Esan Stdt Assoc. Nig, 3.

Shallenberger, R. S. (1993). Taste chemistry. Springer. 120.

Akanji, M.A., Olagoke, O.A and Oloyede, O.B. (1993). Effect of chronic consumption of metabisulphite on the integrity of rat liver cellular system. Toxiol, 81: 173-179.

Allen P.J. (2012). Creatine metabolism and psychiatric disorders: Does creatine supplementation have therapeutical value? Neurosci. Behav. Rev. 36: 1442-1462.

Coso, J., Estevez, E., Mora-Rodriguez, R. (2008). Caffeine effects on short-term performance during prolonged exercise in the heat. Med Sci Sports Exerc 40:744-751.

Eruola A.O., Ufoegbune G.C., Awomeso J.A., Adeofun C.O., Idowu O.A. and Sowunmi A. (2010) Qualitative and Quantitative Assessment of Rainwater Harvesting from Rooftop Catchments: Case Study of Oke-Lantoro Community in Abeokuta, Southwest Nigeria. Europ. Wat. 32: 47-56.

Hadwen, P. (1987). Caribbean Islands: A Review of Roof and Purpose Built Catchments. In NonConventional Water Resources Use in Developing Countries. New York, United Nations, pp. 455-468.
Hellgren, Mikko; Sandberg, Lars; Edholm, Olle (2006). A comparison between two prokaryotic potassium channels $\left(\mathrm{K}_{\mathrm{ir}} \mathrm{Bac1.1}\right.$ and $\left.\mathrm{KcsA}\right)$ in a molecular dynamics (MD) simulation study Biophysic Chem 120 (1): 1-9.

Meera V. and Ahammed M.M. (2006). Water quality of rooftop rainwater harvesting systems: a review. Journal of water supply - research and technology - Aqua;55, (4 ) 257-268.

Purves W.K., David S., Gordon H.O., Heller H.C. (2004) Life: The Science of Biology 7th ed.) Sunderland, Mass: Sinauer Associates. 954.

Noakes T.D., Goodwin N., Rayner B.L., Branken T. and Taylor R.K. (2005). Water intoxication: a possible complication during endurance exercise, 1985". Wilderness Environ Med 16 (4): 221-7.

Shahjahan, M.T., Sabitha, K.E., Jamu, M, and Shyamala-Devi, C.S. (2004). Effect of Solanum trilobatum against carbon tetrachloride induced hepatic damage in albino rats. Indian J. Med. Res., 120: 194-198.

Shmueli, D.F. (1999). Water quality in international river basins. Pol. Geog 18: 437-476.

Yakubu, M.T., Bilbis, L.S., Lawal, M. and Akanji, M.A. (2003). Evaluation of selected parameters of rat liver and kidney function following repeated administration of yohimbine". Biokemistri, 15(2): 50-56.

Yakubu, M.T., Salau, I.O. and Muhammad, N.O. (2003b). Phosphate activities in selected rat tissues following repeated administration of ranitidine. Nig. J. Biochem. Mol. Biol., 18(1): 21-24. 